\title{
Multimodality Imaging of Subcutaneous Panniculitis-like T-cell Lymphoma
}

\author{
Takashi Ushiki ${ }^{1,2}$, Koji Nikkuni ${ }^{2}$, Takeshi Higuchi ${ }^{3}$ and Kazue Takai ${ }^{2}$ \\ Key words: subcutaneous panniculitis-like T-cell lymphoma, computed tomography, magnetic resonance im- \\ aging
}

(Intern Med 50: 1265, 2011)

(DOI: 10.2169/internalmedicine.50.5338)

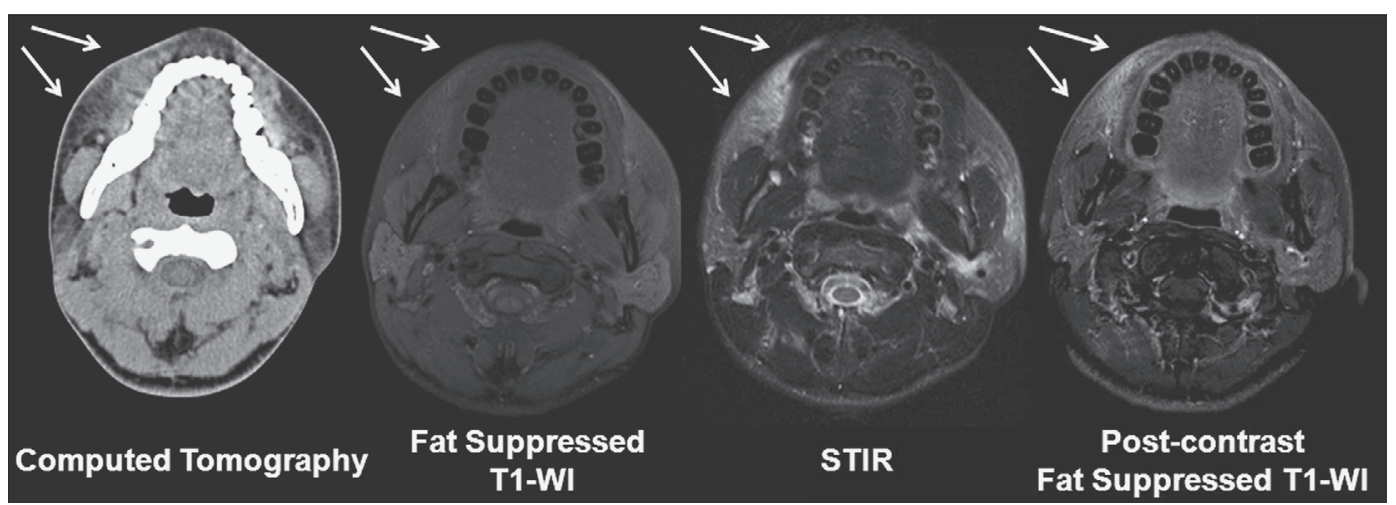

Picture 1.

A 17-year-old man admitted for trachelophyma was diagnosed with subcutaneous panniculitis-like T-cell lymphoma (SPTCL) (1). Computed tomography showed increased density of buccal subcutaneous fat tissue. Magnetic resonance imaging showed low intensity on fat-suppressed T1weighted imaging and high intensity on short tau inversion recovery (STIR) imaging. The lesion was enhanced with gadolinium on fat-suppressed T1-weighted imaging (Picture 1, arrows). The skin biopsy specimen showed infiltration of subcutaneous fatty tissue by various sized atypical lymphocytes, which is typical for SPTCL. The infiltrating cells had the $\mathrm{CD}^{+}, \mathrm{CD} 4, \mathrm{CD}^{+}, \mathrm{CD} 56$ phenotype and expressed cytotoxic molecules [e.g., granzyme B, T-cell intracellular antigen (TIA-1)] and $\beta \mathrm{F} 1$. In situ hybridization yielded negative results for Epstein Barr virus-encoded RNA.
An accurate diagnosis of SPTCL is difficult because it is usually confused with benign panniculitis. Multiple enhancing nodules are sometimes observed in SPTCL (2); multimodality imaging facilitates the evaluation of subcutaneous nodules and diagnosis of SPTCL in such cases.

The authors state that they have no Conflict of Interest (COI).

\section{References}

1. Willemze R, Jansen PM, Cerroni L, et al. Subcutaneous panniculitis-like T-cell lymphoma: definition, classification, and prognostic factors: an EORTC Cutaneous Lymphoma Group Study of 83 cases. Blood 111: 838-845, 2008.

2. Lee HJ, Im JG, Goo JM, et al. Peripheral T-cell lymphoma: spectrum of imaging findings with clinical and pathologic features. Radiographics 23: 7-26, 2003.

\footnotetext{
${ }^{1}$ Department of Hematology, Niigata University Graduate School of Medical and Dental Sciences, Japan, ${ }^{2}$ Department of Hematology, Niigata City General Hospital, Japan and ${ }^{3}$ Department of Radiology, Niigata City General Hospital, Japan

Received for publication February 17, 2011; Accepted for publication March 7, 2011

Correspondence to Dr. Takashi Ushiki, tushiki@med.niigata-u.ac.jp

(C) 2011 The Japanese Society of Internal Medicine Journal Website: http://www.naika.or.jp/imindex.html
} 